\title{
KORELASI REWARD DAN PUNISHMENT TERHADAP MOTIVASI BELAJAR SISWA PADA MATA PELAJARAN PENDIDIKAN AGAMA ISLAM DI SMA NEGERI 1 SALIMPAUNG KABUPATEN TANAH DATAR
}

\section{Yayan Rahadian}

Mahasiswa Program Pascasarjana IAIN Batusangkar, Program Studi Pendidikan Agama Islam e-mail: yayanrahadian@yahoo.co.id

\begin{abstract}
The problem in this research was students motivation in Islamic education in high school 1 Salimpaung is well. Researcher suppose that this condition process. The purpose of this research was to know the correlation of reward toward student motivation, punishment toward students motivation and the correlation both of reward and punishment toward students motivation. This research is quantitative research that applied correlation method. The population in this research were all of the students in high school 1 Salimpaung in 2016/2017. It was consists of 417 students. While, the sample was only 81 students that was taken by using proportional stratified random sampling technique. The variable data $X 1, X 2$, and Y collected by using questioner with liker scale. The first and second hypothesis tested by using simple regression technique. While the third hypothesis tested by using double regression. The result of this research indicate that the correlation of reward toward students motivation was $0,1 \%$, then correlation of punishment toward students motivation was 10,3\%. While the correlation both reward and punishment toward students motivation was $10,4 \%$.
\end{abstract}

Keywords: Reward, Punishment, Student Motivation, Islamic Education

\section{PENDAHULUAN}

Pendidikan mempunyai peran untuk meningkatkan sumber daya manusia, maka masyarakat dengan segala kesadarannya untuk menyengolahkan anak-anaknya. Hal ini dapat dilihat pada setiap tahun ajaran baru, dalam setiap tahunnya jumlah siswa semakin meninggkat dan ini tidak menutup kemungkinan timbul berbagai masalah yang dihadapi oleh para guru. Di mana jika melihat pendidikan sekarang ini yang berhubungan dengan tingkah laku siswa, terjadi banyak penyimpangan dan tidak sesuai dengan harapan yang diinginkan. Ini terbukti dengan banyaknya moral dan akhlak siswa yang tidak sesuai dengan tujuan pendidikan itu sendiri. Misalnya; perkelahian antar siswa, terlambat, melalaikan tugas, membolos, berisik di kelas, saling kirim surat disaat pelajaran, membantah perintah dan sebagainya.

Penyimpangan lain dari siswa dalam kegiatan belajar mengajar yaitu sering tidak 
fokus dan tidak memperhatikan pada pelajaran yang disampaikan oleh guru yang di depan, dengan keadaan yang demikian seorang guru harus bisa menguasai kelas dan mengkondisikan siswa yang perhatiannya mulai terpecah, sebagai seorang guru haruslah mampu memberikan motivasi bagi siswa, bagaimana caranya bahwa belajar itu tidak membosankan melainkan menyenangkan, ini merupakan tantangan bagi guru, seorang guru harus tahu cara yang tepat untuk membuat suasana belajar yang menarik terutama pada mata pelajaran Pendidikan Agama Islam, sering kali siswa malas belajar Pendidikan Agama Islam itu dikarenakan, merasa jenuh, suasana belajar yang tidak nyaman dan membosankan, karena dalam kegiatan belajar mengajar hanya menggunakan ceramah dan hafalan saja.

Untuk mengatasi masalah tersebut serta mampu memberi motivasi belajar bagi siswa agar proses pendidikan bisa berjalan dengan lancar dan berhasil, maka diadakan upaya pencegahan dalam berbagai macam seperti peraturan-peraturan tata tertib, peraturan itu harus ditaati dan dilaksanakan oleh siswa demi meningkatkan kualitas dan prestasi belajar siswa, namun ada cara lain yang bisa diterapkan yaitu dengan memberi motivasi belajar Pendidikan Agama Islam dengan memberikan reward (ganjaran) dan punishment (hukuman). Reward dan punishmen adalah sebagai salah satu alat pendidikan untuk mempergiat usaha siswa untuk memperbaiki atau mempertinggi prestasi yang telah dicapai.
Reward yaitu hadiah, pembalas jasa, alat pendidikan yang diberikan kepada siswa yang telah mencapai prestasi baik (M.Sastra Pradja: 1978: 169). Sedangkan menurut M. Ngalim Purwanto (2006: 182) reward (ganjaran) adalah sebagai alat untuk mendidik anak-anak supaya anak dapat merasa senang karena perbuatan atau pekerjaannya mendapat penghargaan. Sementara itu Amir Daien Indrakusuma (1973: 147) reward merupakan hal yang menggembirakan bagi anak, dan dapat menjadi pendorong atau motivasi bagi belajarnya murid. Punishmen (hukuman) merupakan usaha edukatif untuk memperbaiki dan mengarahkan siswa kearah yang benar, bukan praktik hukuman dan siksaan yang memasung kreativitas (Malik Fadjar: 2005: 202).

Dengan demikian, reward (ganjaran) dan punishmen (hukuman), di samping berfungsi sebagai alat-alat pendidikan, maka sekaligus berfungsi sebagai motivasi bagi belajar murid. Motivasi adalah keadaan dalam pribadi orang yang mendorong individu untuk melakukan aktivitas-aktivitas tertentu guna mencapai sesuatu tujuan (Sumadi Suryabrata: 2005: 70). Menurut Tadjab (2007: 23) motivasi belajar adalah keseluruhan daya penggerak psikis di dalam diri siswa yang menimbulkan kegaiatan belajar, menjamin kelangsungan kegaiatan belajar dan memberikan arah pada kegiatan belajar demi mencapai tujuan tertentu. Hamzah B. Uno (2007: 85) mengemukakan motivasi belajar adalah dorongan internal dan 
eksternal pada siswa-siswa yang sedang belajar untuk mengadakan perubahan tingkah laku.

Dari uraian di atas dapat diketahui bahwa reward dan punishment di samping sebagai alat pendidikan juga sebagai motivasi bagi siswa dalam mencapai prestasi belajar siswa setinggi-tingginya. Untuk itu diperlukan adanya pemberian reward (ganjaran) dan punishment (hukuman) di sekolah-sekolah.

\section{KAJIAN TEORI}

\section{Reward}

Reward (ganjaran), berasal dari bahasa Inggris reward yang berarti penghargaan atau hadiah (John M. Echols dan Hasan Shadily: 1996: 485). Sedangkan secara istilah ada beberapa pendapat yang mengemukakan pengertian reward (ganjaran), yaitu; menurut M. Ngalim Purwanto (2006: 182) ialah alat untuk mendidik anak-anak supaya anak dapat merasa senang karena perbuatan atau pekerjaannya mendapatkan penghargaan. Menurut Amir Daien Indrakusuma (1973: 159) reward merupakan penilaian yang bersifat positif terhadap belajarnya siswa.

Secara garis besar reward (ganjaran) dapat dibedakan menjadi empat macam, yaitu:
a. Pujian
b. Penghormatan
c. Hadiah
d. Tanda Penghargaan

Maksud dari reward (ganjaran) itu yang terpenting bukanlah hasil yang dicapai seorang siswa, tetapi dengan hasil yang dicapai siswa, guru bertujuan membentuk kata hati dan kemauan yang lebih baik dan lebih keras pada siswa. Reward di samping merupakan alat pendidikan represif yang menyenagkan, reward juga dapat menjadi pendorong atau motivasi bagi siswa untuk belajar lebih baik.

\section{Punishment}

Hukuman secara Bahasa berasal dari Bahasa Inggris, yaitu dari kata punishment yang berarti Law (hukuman) atau siksaan (John M. Echols dan Hasan Shadily: 1996: 456). Secara istilah ada beberapa pendapat dari para ahli yang mengemukakan tentang punishment(hukuman), yaitu; menurut Malik Fadjar (2005: 202) punishment (hukuman) adalah usaha edukatif untuk memperbaiki dan mengarahkan siswa ke arah yang benar, bukan praktik hukuman dan siksaan yang memasung kreativitas. Sedangkan Roestiyah (1978: 63) mengemukakan punishment (hukuman) merupakan suatau perbuatan yang tidak menyenangkan dari orang yang lebih tinggi kedudukannya untuk pelanggalaran dan kejahatan, bermaksud memperbaiki kesalahan anak. M. Ngalim Purwanto (2006: 186) mengemukakan punishment (hukuman) adalah penderitaan yang diberikan atau ditimbulkan dengan sengaja oleh seseorang (orang tua, guru dan sebagainya) sesudah terjadi suatu pelanggaran, kejahatan atau kesalahan. Sementara itu Abu Ahmadi dan Abu Uhbiyati dalam bukunya Ilmu Pendidikan 
(199: 150) punishment (hukuman) adalah suatu perbuatan, di mana kita secara sadar dan senagaj menjatuhkan nestapa kepada orang lain, yang baik dari segi kejasmanian maupun dari segi kerohanian orang lain itu mempunyai kelemahan bila dibandingkan dengan diri kita, dan oleh karena itu maka kita mempunyai tanggung jawab untuk membimbingnya dan melindunginya.

Dari beberapa pendapat di atas, peneliti dapat menarik kesimpulan, bahwa punishment (hukuman) adalah suatu perbuatan yang kurang menyenagkan, yang berupa penderitaan yang diberikan kepada siswa secara sadar dan senagaj, sehingga sadar hatinya untuk tidak mengulangi lagi. Punishment diberikan bukan sebagai bentuk siksaan baik fisik maupun rohani, malinkan sebagai usaha mengembalikan siswa ke arah yang baik.

\section{Motivasi Belajar}

Istilah motivasi berasal dari kata "motif" yang dapat diartikan sebagai kekuatan yang terdapat dalam diri individu, yang menyebabkan individu tersebut bertindak atau berbuat. Motif adalah daya penggerak dalam diri seseorang untuk melakukan aktivitas tertentu, demi mencapai tujuan tertentu. Dengan demikian, motivasi merupakan dorongan yang terdapat dalam diri seseorang untuk berusaha mengadakan perubahan tingkah laku yang lebih baik dalam memenuhi kebutuhannya. (Hamzah B. Uno: 2007: 3). Tajdab (1994: 101) mengemukakan motivasi adalah motif yang sudah menjadi aktif pada saat-saat tertentu,
Sardiman (2007: 75) mengemukakan kalau motivasi dapat juga diartikan serangkaian usaha untuk menyediakan kondisi-kondisi tertentu, sehingga seseorang mau dan ingin melakukan sesuatu, dan bila ia tidak suka, maka akan berusaha untuk meniadakan atau mengelakkan perasaan tidak suka itu.

\section{METODOLOGI PENELITIAN}

Jenis penelitian yang digunakan dalam penelitian ini adalah penelitian kuantitaif. Menurut Siggih dalam Suyanto (2207: 135) menjelaskan bahwa penelitian kuantitattif adalah penelitian yang: Pertama, melibatkan lima komponen informasi ilmiah, yaitu; teori, hipotesis, observasi, generalisasi empiris, dan penerimaan atau penolakan hipotesis. Kedua, mengadakan adanya populasi dan teknik penarikan sampel. Ketiga, menggunakan kuesioner untuk pengumpulan data. Keempat, mengemukakan variabel-variabel penelitian dalam analisis datanya dan kelima, berupaya menghasilkan kesimpulan secara umum, baik yang berlaku untuk populasi atau sampel yang diteliti.

Metode penelitian yang digunakan adalah metode penelitian korelasional. Penelitian korelasional merupakan penelitian yang dimaksudkan untuk mengetahui ada tidaknya hubungan antara dua variabel atau beberapa variabel. (Suharsimi Arikunto: 2005: 247). Tujuan penelitian korelasional adalah untuk mengidentifikasi hubungan prediktif dengan menggunakan teknik 
korelasi atau teknik statistic yang lebih canggih. Dengan kata lain, tujuan studi korelasional adalah untuk menentukan hubungan antara variabel atau untuk menggunakan hubungan tersebut untuk membuat prediksi. (Emzir: 2011: 37).

Tekhnik pengumpulan data dalam penelitian ini berupa angket (questionare). Menurut Sugiyono (1999) angket (questionare) adalah daftar pernyataan yang diberikan kepada orang lain yang bersedia memberikan respon (responden) sesuai dengan permintaan pengguna. Angket dibedakan menjadi dua jenis yaitu:

\section{Angket terbuka}

Angket terbuka (angket tidak berstruktur) ialah angket yang disajikan dalam bentuk sederhana sehingga responden dapat memberikan isian sesuai dengan kehendak dan keadannya.

2. Angket tertutup

Angket tertutup (angket berstruktur) adalah angket yang disajikan dalam bentuk sedemikian rupa sehingga responden diminta untuk memilih satu jawaban yang sesuai dengan karakteristik dirinya dengan cara memberikan tanda silang $(\mathrm{X})$ atau tanda checklist $(\mathrm{v})$.

Angket yang digunakan dalam penelitian ini adalah angket tertutup. Angket ini digunakan untuk mencari data reward $\left(\mathrm{X}_{1}\right)$, punishment $\left(\mathrm{X}_{2}\right)$, dan motivasi belajar (Y) siswa SMA Negeri 1 Salimpaung. Angket disebarkan dan diisi oleh siswa SMA
Negeri 1 Salimpaung yang menjadi sampel penelitian. Jumlah sampel penelitian dalam penelitian ini adalah 81 orang.

Daftar pernyataan yang disajikan diukur dengan menggunakan model skala likert. Sugiyono menegaskan bahwa skala likert dapat digunakan untuk mengukur sikap, pendapat, dan persepsi seseorang atau kelompok tertentu tentang fenomena sosial.

\section{HASIL PENELITIAN DAN PEMBAHASAN}

Data dalam penelitian ini meliputi tiga variabel yaitu data motivasi belajar (Y), pemberian reward $\left(\mathrm{X}_{1}\right)$ dan pemberian punishment $\left(\mathrm{X}_{2}\right)$ pada mata pelajaran Pendidikan Agama Islam terhadap siswa SMA Negeri 1 Salimpaung.

\section{Pemberian Reward terhadap Siswa $\left(\mathbf{X}_{\mathbf{1}}\right)$}

Hasil analisis data dan pengujian hipotesis menunjukkan bahwa pada variabel pemberian reward tidak terdapat korelasi secara signifikan terhadap variabel motivasi belajar siswa pada mata pelajaran Pendidikan Agama Islam. Hasil analisis juga menunjukkan bahwa pemberian reward hanya memberikan kontribusi sebesar $0,1 \%$ terhadap motivasi belajar siswa pada mata pelajaran Pendidikan Agama Islam di SMA Negeri 1 Salimpaung. Ini berarti apabila semakin sering diberikan reward kepada siswa dalam proses pembelajaran maka motivasi belajar siswa cenderung akan meningkat dan begitu juga sebaliknya. 
Hal ini sejalan dengan teori yang dikemukakan oleh Amir Daien Indrakusuma (1973) yang menyatakan bahwa "reward (ganjaran) adalah penilain yang bersifat positif terhadap belajar siswa". Maksud dari pendidik memberikan reward (ganjaran) kepada siswa adalah supaya siswa menjadi lebih giat lagi usahanya untuk memperbaiki atau mempertinggi prestasi yang telah dicapainya, dengan kata lain siswa menjadi lebih keras kemauannya untuk belajar lebih baik.

\section{Pemberian Punishment terhadap Siswa $\left(\mathrm{X}_{2}\right)$}

Hasil analisis data dan pengujian hipotesis menunjukkan bahwa variabel pemberian punishment berpengaruh terhadap variabel motivasi belajar siswa. pemberian punishment memberikan kontribusi sebesar 10,3\% terhadap motivasi belajar siswa pada mata pelajaran Pendidikan Agama Islam di SMA Negeri 1 Salimpaung. Dengan demikian dapat diyakini bahwa pemberian punishment berkontribusi terhadap motivasi belajar siswa pada mata pelajaran Pendidikan Agama Islam di SMA Negeri 1 Salimpaung. Ini berarti apabila semakin sering diterapkannya punishment terhadap siswa yang melakukan kesalahan dalam proses pembelajaran, maka akan semakin baik motivasi belajar siswa tersebut dan begitu juga sebaliknya.

Hasil penelitian ini sejalan dengan teori yang dikemukakan oleh Malik Fadjar (2005: 202) yang menyatakan bahwa "punishment (hukuman) adalah usaha edukatif untuk memperbaiki dan mengarahkan siswa kearah yang benar, bukan prakrik hukuman dan siksaan yang memasung kreatifitas". Dengan adanya punishment (hukuman) itu diharapkan supaya siswa dapat menyadari kesalahan yang diperbuatnya, sehingga siswa jadi berhati- hati dalam mengambil tindakan

\section{Motivasi Belajar Siswa (Y)}

Hasil analisis data dan pengujian hipotesis menunjukkan bahwa variabel motivasi belajar siswa pada mata pelajaran Pendidikan Agama Islam di SMA Negeri 1 Salimpaung berada pada kategori sangat baik. Hal ini sejalan dengan banyaknya responden yang skornya berada pada posisi sangat baik yaitu 35 orang dari 81 responden atau $43,00 \%$ dari seluruh responden yang ada.

Temuan penelitian ini menunjukkan bahwa motivasi belajar siswa pada mata pelajaran Pendidikan Agama Islam di SMA Negeri 1 Salimpaung berada pada kategori sangat baik.

\section{Analisis Data}

Pengujian hipotesis pada penelitian ini menggunakan teknik analisis regresi. Pemeriksaan persyaratan analisis dilakukan dengan menggunakan bantuan program SPSS versi 18.0. Sebelum data dianalisis, terlebih dahulu dilakukan uji normalitas, uji homogenitas, uji independen, dan uji linearitas.

\section{Uji Normalitas Data}

Pengujian normalitas terhadap skor motivasi belajar siswa $(\mathrm{Y})$, pemberian 
reward $\left(\mathrm{X}_{1}\right)$ dan pemberian punishment $\left(\mathrm{X}_{2}\right)$ dilakukan dengan menggunakan teknik Kolmogorof Smirnov- $Z$ dengan menetapkan taraf signifikansi 5\% $(\alpha=0,05)$. Data dikatakan berdistribusi normal apabila probabilitas yang diperoleh atau $\rho>\alpha=0,05$

Nilai signifikansi variabel motivasi belajar siswa $(Y)$ sebesar 0,086>0,05. Nilai signifikansi variabel pemberian reward $\left(\mathrm{X}_{1}\right)$ sebesar 0,22>0,05dan nilai signifikansi variabel pemberian punishment $\left(\mathrm{X}_{2}\right)$ adalah 0,183>0,05. Dengan demikian dapat dinyatakan bahwa ketiga data variabel terdistribusi dengan normal sehingga persyaratan analisis regresi untuk normalitas sebaran data dapat dipenuhi.

\section{Uji Homogenitas}

Persyaratan selanjutnya yang perlu dipenuhi adalah persyaratan homogenitas data kelompok. Uji homogenitas dilakukan untuk mengetahui apakah sampel penelitian berasal dari populasi yang homogen. Pemeriksaan homogenitas dilakukan dengan menggunakan teslevene statistic dengan menggunakan taraf signifikansi 5\% atau $\alpha=0,05$. Data dinyatakan homogen apabila memenuhi persyaratan bahwa skor signifikansi (sig.) >0,05. Sebaliknya, jika skor signifikansi (sig) $<0,05$ maka data dinyatakan tidak homogen.

Berdasarkan hasil perhitungan dengan menggunakan SPSS, tampak nilai $\mathbf{r}$ (sig.) lebih besar dari $\alpha$ yang digunakan $(0,05)$. Maka dapat disimpulkan bahwa skor pada masing-masing variabel menyebar secara homogen. Dengan demikian, persyaratan analisis regresi untuk homogenitas sebaran data sebagai persyaratan dapat dipenuhi.

\section{Uji Multikolinearitas}

Uji multikolinearitas dilakukan untuk memastikan tidak terjadi pembaruan (kontaminasi dalam kontribusi masingmasing variabel bebas terhadap variabel terikat). Pengambilan keputusan dalam uji multikolinearitas ini adalah apabila nilai tolerance $>0,10$ dan nilai VIF $<10$, maka tidak terdapat multikolinearitas dalam data atau dalam pengertian lain data dinyatakan independen. Namun sebaliknya, jika nilai tolerance $<0,10$ dan nilai VIF $>10$, maka terdapat multikolinearitas dalam data atau dalam pengertian lain data dinyatakan tidak independen.

Berdasarkan hasil perhitungan dengan menggunakan SPSS, tampak nilai VIF $(43,789)>10$ dan nilai tolerance $(0,23)$ $<$ 0,10. Maka dapat disimpulkan bahwa kedua variabel tersebut saling bebas atau independen.

\section{Uji Linearitas}

Uji linearitas dilakukan untuk mengetahui apakah sebaran data masingmasing variabel bebas cenderung membentuk garis linear dengan sebaran data variabel terikat. Pemeriksaan linearitas dilakukan dengan teknik One Way Anova dengan menggunakan tarif signifikansi 5\% $(\alpha=0,05)$. 
Berdasarkan hasil perhitungan dengan menggunakan SPSS, tampak nilai signifikansi (sig.) variabel $X_{1}$ terhadap $Y(0,174)$ lebih besar dari $\alpha$ yang digunakan (0,05). Kemudian Fhitung $(1,376)$ lebih kecil Ftabel $(3,12)$. Maka dapat disimpulkan bahwa terdapat hubungan linear secara signifikan antara variabel pemberian reward $\left(\mathrm{X}_{1}\right)$ dengan variabel belajar siswa $(\mathrm{Y})$.

Sedangkan hasil perhitungan linearitas antara variabel pemberian punishment $\left(\mathrm{X}_{2}\right)$ dengan variabel motivasi belajar siswa $(\mathrm{Y})$ menunjukkan nilai signifikansi $0,947>$ 0,05. Sedangkan Fhitung $(0,493)<$ Ftabel $(3,12)$. Maka dapat disimpulkan bahwa terdapat hubungan linear secara signifikan antara variabel pemberian punishment $\left(\mathrm{X}_{2}\right)$ dengan Variabel motivasi belajar $(\mathrm{Y})$.

\section{PENGUJIAN HIPOTESIS}

\section{a. Hipotesis Pertama}

Hipotesis pertama yang diuji dalam penelitian ini adalah "Korelasi pemberian reward pada mata pelajaran Pendidikan Agama Islam terhadap motivasi belajar siswa di SMA Negeri 1 Salimpaung”. Untuk mengetahui apakah pemberian reward ada korelasi terhadap motivasi belajar, maka digunakan uji koefisien korelasi (uji r). Rumusan hipotesisnya adalah:

$\mathrm{H}_{0}$ : Tidak terdapat korelasi secara signifikan antara pemberian reward terhadap motivasi belajar siswa pada mata pelajaran Pendidikan Agama Islam di SMA Negeri 1 Salimpaung.

$H_{1}$ : Terdapat korelasi secara signifikan antara pemberian reward terhadap motivasi belajar siswa pada mata pelajaran Pendidikan Agama Islam di SMA Negeri 1 Salimpaung.

Tingkat signifikansi yang digunakan $5 \%(\alpha=0,05)$. Kriteria pengujian $\mathrm{H}_{0}$ diterima dan $\mathrm{H}_{1}$ ditolak jika $\mathrm{t}_{\text {hitung }}<\mathrm{t}_{\text {tabel }}$. Akan tetapi, jika $\mathrm{t}_{\text {hitung }}>\mathrm{t}_{\text {tabel }}$ maka $\mathrm{H}_{0}$ ditolak dan $\mathrm{H}_{1}$ diterima. Hasil perhitungan regresi sederhana antara variabel pemberian reward terhadap variabel motivasi belajar siswa pada mata pelajaran Pendidikan Agama Islam di SMA Negeri 1 Salimpaung dapat disimpulkan bahwa pemberian reward berkontribusi signifikan sebesar 0,1\% terhadap motivasi belajar siswa pada mata pelajaran Pendidikan Agama Islam di SMA Negeri 1 Salimpaung. Dengan demikian dapat diartikan bahwa motivasi belajar siswa pada mata pelajaran Pendidikan Agama Islam di SMA Negeri 1 Salimpaung sebesar $0.1 \%$ ditentukan oleh pemberian reward oleh guru terhadap siswa. Sedangkan 99,9\% lagi ditentukan oleh faktor lain yang tidak dimasukkan ke dalam penelitian ini. 


\section{b. Hipotesis Kedua}

Hipotesis kedua yang diuji dalam penelitian ini adalah "Korelasi Pemberian Punishment terhadap Motivasi Belajar Siswa pada Mata Pelajaran Pendidikan Agama Islam di SMA Negeri 1 Salimpaung". Untuk mengetahui apakah pemberian punishment terdapat korelasi secara signifikan terhadap motivasi belajar siswa, maka digunakan uji koefisien regresi (uji t). Rumusan hipotesisnya adalah:

$\mathrm{H}_{0}$ : Tidak terdapat korelasi yang signifikan antara pemberian punishment terhadap motivasi belajar siswa pada mata pelajaran Pendidikan Agama Islam di SMA Negeri 1 Salimpaung.

\section{$H_{1}$ : Terdapat korelasi yang} signifikan antara pemberian punishment terhadap motivasi belajar siswa pada mata pelajaran Pendidikan Agama Islam di SMA Negeri 1 Salimpaung.

Dapat disimpulkan bahwa pemberian punishment berkontribusi signifikan sebesar $10,3 \%$ terhadap motivasi belajar siswa pada mata pelajaran Pendidikan Agama Islam di SMA Negeri 1 Salimpaung. Dengan demikian dapat diartikan bahwa motivasi belajar siswa pada mata pelajaran Pendidikan Agama Islam di SMA Negeri 1 Salimpaung sebesar $10,3 \%$ ditentukan oleh pemberian punishment oleh guru terhadap siswa.
Sedangkan 89,7\% lagi ditentukan oleh faktor lain yang tidak dimasukkan ke dalam penelitian ini.

\section{c. Hipotesis Ketiga}

Hipotesis ketiga yang diuji dalam penelitian ini adalah "terdapat korelasi yang signifikan antara pemberian reward dan punishment secara bersama-sama terhadap motivasi belajar siswa pada mata pelajaran Pendidikan Agama Islam di SMA Negeri 1 Salimpaung”. Untuk mengetahui apakah terdapat korelasi yang signifikan antara pemberian reward dan punishment secara bersama-sama terhadap motivasi belajar siswa pada mata pelajaran Pendidikan Agama Islam di SMA Negeri 1 Salimpaung, maka digunakan uji multiple regression (uji F). Rumusan hipotesisnya adalah:

$\mathrm{H}_{0}$ : Tidak terdapat korelasi yang signifikan antara pemberian reward dan punishment secara bersama-sama terhadap motivasi belajar siswa pada mata pelajaran Pendidikan Agama Islam di SMA Negeri 1 Salimpaung.

$\mathrm{H}_{1}$ : Terdapat korelasi yang signifikan antara pemberian reward dan punishment secara bersama-sama terhadap motivasi belajar siswa pada mata pelajaran Pendidikan Agama Islam di SMA Negeri 1 Salimpaung.

Tingkat signifikansi yang digunakan 5\% $(\alpha=0,05)$. 
Kriteria pengujian $\mathrm{H}_{0}$ diterima dan $\mathrm{H}_{1}$ ditolak jika $\mathrm{F}_{\text {hitung }}<\mathrm{F}_{\text {tabel }}$. Akan tetapi, jika $\mathrm{F}_{\text {hitung }}>\mathrm{F}_{\text {tabel }}$ maka $\mathrm{H}_{0}$ ditolak dan $\mathrm{H}_{1}$ diterima. Hasil perhitungan harga Fhitung sebesar 4,551 dengan nilai signifikansi sebesar 0,00. Kemudian dilihat Ftabel dengan tingkat keyakinan $95 \%$ untuk $\mathrm{df}$ pembilang $(\mathrm{df}=$ $\mathrm{k}-1=3-1=2)$ dan $\mathrm{df}$ penyebut $(\mathrm{df}=\mathrm{n}-\mathrm{k}=$ $81-3=78)$ yaitu 2,37. Setelah dibandingkan $\mathrm{F}_{\text {hitung }}$ dengan $\mathrm{F}_{\text {tabel }}$, maka didapatkan hasil $\mathrm{F}_{\text {hitung }}>\mathrm{F}_{\text {tabel }}(4,551>2,37)$. Karena $\mathrm{F}_{\text {hitung }}>$ $\mathrm{F}_{\text {tabel' }}$ maka $\mathrm{H}_{0}$ ditolak dan $\mathrm{H}_{1}$ diterima. Artinya, Terdapat korelasi yang signifikan antara pemberian reward dan punishment secara bersama-sama terhadap motivasi belajar siswa pada mata pelajaran Pendidikan Agama Islam di SMA Negeri 1 Salimpaung.

\section{KESIMPULAN}

Dari peneelitian yang penulis lakukan di SMA Negeri 1 Salimpaung Kabupaten Tanah Datar ditemukan bahwa:

1. Tidak terdapat korelasi secara signifikan antara pemberian reward terhadap motivasi belajar siswa pada mata pelajaran Pendidikan Agama Islam di SMA Negeri 1 Salimpaung. Besarnya korelasi pemberian reward terhadap motivasi belajar siswa pada mata pelajaran Pendidikan Agama Islam di SMA Negeri 1 Salimpaung Kabupaten Tanah Datar hanya sebesar $0,1 \%$, ini berarti apabila semakin sering diberikan reward kepada siswa dalam proses pembelajaran maka motivasi belajar siswa akan semakin meningkat dan begitu juga sebaliknya.

2. Terdapat korelasi secara signifikan antara pemberian punishment terhadap motivasi belajar siswa pada mata pelajaran Pendidikan Agama Islam di SMA Neger 1 Salimpaung Kabupaten Tanah Datar adalah sebesar $10,3 \%$, ini juga berarti bahwa apabila diberikan punishment terhadap siswa yang melakukan kesalahan dalam proses pembelajaran, maka motivasi belajar siswa akan semakin meningkat dan begitu juga sebaliknya.

3. Terdapat korelasi secara signifikan antara pemberian reward dan punishment secara bersama-sama terhadap motivasi belajar siswa pada mata pelajaran Pendidikan Agama Islam di SMA Negeri 1 Salimpaung Kabupaten Tanah Datar, besar pengaruhnya adalah $10,4 \%$ ini berarti apabila pemberian reward dan punishment secara bersama-sama semakin ditingkatkan, maka motivasi belajar siswa juga akan semakin baik dan begitu juga sebaliknya.

\section{Saran}

1. Kepada Kepala sekolah SMA Negeri 1 Salimpaung untuk dapat lebih meningkatkan lagi pemberian reward dan punishment terhadap siswa. Sehingga, diharapkan motivasi belajar siswa juga menjadi lebih baik.

2. Kepada Majelis guru dan pegawai SMA Negeri 1 Salimpaung untuk dapat 
bekerja sama dalam meningkatkan motivasi belajar siswa. Para guru dan karyawan harus memberikan contoh teladan yang baik sehingga siswa juga termotivasi untuk mengikutinya.

3. Kepada pemerintah agar berusaha untuk menerapkan kebijakan- kebijakan yang dapat meningkatkan motivasi belajar siswa sehingga terbentuk motivasi belajar yng tinggi dalam diri siswa.

4. Bagi peneliti lain yang tertarik untuk melakukan pengkajian lebih mendalam tentang motivasi belajar siswa agar lebih memperluas bahasan tentang faktor- faktor lain yang diduga dapat mempengaruhi motivasi belajar siswa.

\section{KEPUSTAKAAN ACUAN}

Abu Ahmadi dan Abu Uhbiyati. (1991). Ilmu Pendidikan, Jakarta: Rineka Cipta.

Amir Daien Indrakusuma. (1973) Pengantar Ilmu Pendidikan, Surabaya: Usaha Nasional.

Emzir. (2011). Metodologi Penelitian Pendidikan Kuantitatif dan Kualitatif, Jakarta: PT. Raja Grafindo Persada.
Hamzah B. Uno. (2007). Teori Motivasi dan Pengukurannya Analisis di Bidang Pendidikan, Jakarta: Bumi Aksara.

John M. Echols dan Hasan Shadily. (1996). Kamus Inggris Indonesia, Jakarta: Gramedia.

M. Sastra Pradja. (1978) Kamus Istilah Pendidikan dan Umum, Surabaya: Usaha Nasional.

M. Ngalim Purwanto. (2006). Ilmu Pendidikan Teoretis dan Praktis, Bandung: Remaja Rosdakarya.

Malik Fadjar. (2005). Holistika Pemikiran Pendidikan, Jakarta: Raja Grafindo,

Sardiman. (2007). Interaksi dan Motivasi Belajar Mengajar, Jakarta: Rajawali Pers.

Suharsimi Arikunto. (2005). Manajemen Penelitian, Jakarta: Rineka Cipta.

Sumadi Suryabrata. (2005). Psikologi Pendidikan, Jakarta: Raja Grafindo.

Suyanto, dkk. (2007). Metode Penelitian Sosial: Berbagai Alternatif, Jakarta: Kencana. Tadjab, (1994). Ilmu Jiwa Pendidikan, Surabaya: Karya Abditama. 